\title{
MUST THEISTS BELIEVE IN A PERSONAL GOD? Elizabeth Burns
}

The claim that God is a person or personal is, perhaps, one of the most fundamental claims which religious believers make about God. In Hinduism, Brahma, Vishnu and Shiva are represented in person-like form. In the Hebrew Bible/Old Testament God walks in the Garden of Eden (Genesis 3:8), experiences emotions (e.g. Isaiah 61:8), and converses with human beings (e.g. Job 38-41). In the New Testament, God communicates with his people, usually by means of angels or visions (e.g. Matthew 1:2021 ), and retains the ability to speak audibly, as he does to Paul on the Damascus road (Acts 9:4-6). And, in the Qur'an, Allah is said to have a face and two hands (e.g. Qur'an 38:75), to see, and to sit on a throne (e.g. Qur'an 57:4). Many believers today would still claim that, among other things which God can do, he loves those who believe in him (e.g. Ephesians 5:29; I Peter 5:7; Qur'an 1:3) and responds to their prayers (e.g. Matthew 7:7-8; Mark 11:24; Qur'an 11:61).

In this article, I will consider several ways in which God has been understood to be a person or personal and argue that, if God's person-like characteristics must be understood in a metaphorical sense, we cannot draw a clear line between a personal God and an impersonal Absolute.

\section{Is God a person?}

Some scholars have argued that God cannot be 'a person' because God does not possess one or more of the characteristics which a person must have. For example, Brian Davies argues that a person must have a body and 
that, since God is not usually thought to be embodied, God cannot be a person (The Reality of God and the Problem of Evil (London: Continuum, 2006), p. 61). Richard Swinburne, however, simply defines God as 'a person ... without a body' (The Coherence of Theism, $2^{\text {nd }}$ edn. (Oxford: Oxford University Press, 1993), p. 101).

Even if a person need not have a body, God lacks other attributes which persons normally have. For example, it has been argued that he is not capable of abstract thought because divine knowledge is 'complete and intuitive' (Keith Ward, 'Is God a Person?', in Gijsbert van den Brink, Luco J. van den Bron, and Marcel Sarot, eds., Christian Faith and Philosophical Theology: Essays in Honour of Vincent Brummer (Kampen: Kok Pharos, 1992), p. 261.), and that he cannot experience emotions, because to experience emotions is to be changed by something which is not oneself, and the creator of everything cannot be changed by something other than himself (Davies, p. 209). In addition, God has some attributes which persons do not normally have. For example, he is a supremely perfect being, and the creator of everything not himself (Ward, p. 262).

Davies argues that, if God were a person like us, he would be just another inhabitant of the universe whose existence would need an explanation; people are parts of creation and, if God is the creator, he cannot be a person (pp. 62-68). Ward claims that the person model implies that God and human persons are distinct things of the same kind and that this fails to do justice to the idea that God is within us, or that we are one with God (p. 264). Both Davies and Ward make assumptions about the meaning of 'person' here, however. Davies assumes that a person must be created, while Ward infers that the way in which God and human beings relate to each other rules out the possibility that there are enough similarities to justify speaking of both God and human beings as 'persons'. It is therefore possible that God is a person who was not created, who is able to exist within us, and with whom we are one. 
Nevertheless, Davies also points out that, although the Bible often describes God in terms which make him sound like a human being, there are other passages which highlight the differences between God and his creation (e.g. Isaiah 40:18, 25-26, Davies p. 53). In a similar vein, Giles Fraser notes that 'The God of Israel is the God of the burning bush, the God who exists in the cloudy mountaintop, whose face cannot be seen. This is not the God who doubles as my best pal, or who fits a snappy one-line definition. The God who has been at the centre of the Church's life for centuries is a God who is disconcertingly inscrutable, and utterly resistant to cheap certainty' ('Atheists' delusions about God', Church Times, 20 October 2006, p. 11).

Thus, if God is a person, he is a person without a body who lacks some of the attributes which persons normally have, and possesses other attributes which persons do not normally have. He is a person who was not created, a person who exists within us, and with whom we are one. And he is often described in terms which make him seem very different from human beings. Some scholars conclude from this that the word 'person' must be qualified to such an extent when applying it to God that it is no longer meaningful to describe God as 'a person'. But Swinburne argues that God is a person in an analogical sense - i.e. God is a person if he resembles persons more than things which are not persons; it is not necessary for God to resemble persons in every respect. Although the word 'person' means something different from its normal use when applied to God, on Swinburne's view the two uses are sufficiently similar to justify applying the same word to both God and human beings (pp. 283-284). Scholars such as Gary Legenhausen ('Is God a Person?' Religious Studies 22 (1986), pp. 307-323) and William J. Mander ('God and Personality'. Heythrop Journal 38 (1997), pp. 401-412) argue that the analogy fails, however, because God has some features which are incompatible with the analogy e.g. he is perfect, omniscient, infinite and gender neutral. 


\section{Is God personal?}

Some scholars who do not accept that God is in any sense 'a person' prefer to say that God is 'personal' - that, although he is not a person, he has some of the characteristics of a person, and that he has them to a greater extent than we do. But, if it is difficult to accept that God is a person, is it any easier to believe that God is personal? How many of the attributes of a person must God possess in order to be described as 'personal'? Is one sufficient? Arguably not. Although my computer has the ability to acquire, retain, and recall knowledge, few would claim that my computer is personal (except, of course, in the sense that it belongs to me) - at least until there have been significant developments in the science of artificial intelligence.

Perhaps the answer to this question depends upon which characteristic is chosen. It could be argued that the attribute of agency, the ability to act, is central if we want to describe God as personal. Roger Trigg claims that a personal God is an active God, and that a God who has no intentions or purposes cannot be distinguished from a non-existent God (Rationality and Religion: Does Faith Need Reason? (Oxford: Blackwell, 1998), p. 210). For Trigg, loss of belief in an active God leads to loss of religious belief since, in the JudaeoChristian tradition at least, religion is concerned with human relationships with a God who is able to have relationships with human beings (p. 206). As David Pailin has noted ('The Humanity of the Theologian and the Personal Nature of God', Religious Studies 12 (1976), pp. 141-158), religious believers claim that God loves, calls, judges, punishes, and rewards, and all of these describe an action of some kind. If the idea of God acting is incoherent, then it would seem difficult to claim that God is, in any sense, personal.

\section{Difficulties with the concept of God as an agent}

But does it make sense to say that God is an agent? J. L. Gaskin considers whether God's agency is like that of people 
who claim to be able to perform psychokinetic acts - i.e. to make things happen without using their bodies ('Gods, Ghosts and Curious Persons', Philosophical Writing 13 (2000), pp. 71-80). Gaskin thinks that, even if there are people who can do such things, there is no analogy between psychokinetic acts and the actions of a disembodied God.

This is, firstly, because human beings who claim to be able to perform psychokinetic acts have bodies in this world, in which their minds are situated. By contrast, if God does not have a body, he must be a disembodied mind who exists in another world but brings about changes in this world. And, Gaskin says, if this is agency, it is a kind of agency we know nothing about and is therefore not agency in any recognisable sense. Secondly, Gaskin objects that we do not know how the acts of a pure mind or spirit could operate any of the natural processes by means of which the world changes. So, he concludes, there is no similarity between human and divine agency which would enable us to say that divine agency is anything like human agency.

The theist could, of course, maintain that an effect may be caused by the actions of an agent even when we do not understand the means by which the effect was produced. Moreover, the actions of a specific agent are likely to be the cause of the effect when the nature of the effect is consistent with our knowledge of the agent. So, if we think about the existence or apparent design of the world, for example, we might say that these are effects which need to be explained by the agency of a powerful and probably benevolent cause. And, as Clement C. J. Webb has suggested (God and Personality (London: George, Allen and Unwin, 1919), p. 240), belief in the existence of a personal, divine cause might also be supported by religious experience.

\section{Personhood without agency}

Those who remain unconvinced by such arguments (for reasons which I do not have the space to discuss here) 
might turn, instead, to interpretations of God's personhood which do not appear to require belief in divine agency. Examples of these may be found in the work of Paul Tillich (Systematic Theology Volume I: Reason and Revelation, Being and God, $3^{\text {rd }}$ edn (London: SCM Press, 1978)), John Robinson (Honest to God (London: SCM Press, 1963), Exploration into God (London: SCM Press, 1967), and Thou Who Art: The Concept of the Personality of God (London: Continuum, 2006)), Adrian Thatcher ('The Personal God and the God Who is a Person', Religious Studies 21 (1985), pp. 61-73)), and John Hick (An Interpretation of Religion: Human Responses to the Transcendent, $2^{\text {nd }}$ edn (Basingstoke: Palgrave Macmillan, 2004), chapter 15, and The New Frontier of Religion and Science: Religious Experience, Neuroscience and the Transcendent, (Basingstoke: Palgrave Macmillan, 2006)).

For Tillich, God is not 'a heavenly, completely perfect person who resides above the world and mankind' (p. 245) and, for Robinson, there is little evidence for the existence of 'a super-Being beyond this world endowed with personal qualities' (Honest to God, p. 49). Rather, for both Tillich and Robinson, 'God is personal' means that God is the ground of everything personal, that personality is of ultimate significance. Both Robinson and Thatcher regard the God who is described in religious texts as a personification of important spiritual values. In Exploration into God, Robinson suggests that the gods of the Greeks and Romans were personifications of religious convictions (p. 36), but this seems somewhat surprising, given the morally dubious behaviour which often features in the ancient myths. As an interpretation of the God described in the scriptures of the Abrahamic faiths it may, perhaps, be viewed as more promising - although there are, of course, parts of these texts which some would regard as morally suspect. On such a view, the personifications of God which we find in them are humanly-created symbols, albeit symbols which help us in our struggle to grasp the nature of an objectively-existing divinity. 
This view is found more explicitly in the work of Hick, who argues that the 'Ultimate Reality', 'Ultimate', 'Transcendent', or 'Real' may be manifested in either personal or non-personal forms (The New Frontier, p. 162). The Ultimate is neither personal nor impersonal in itself, but attributes like these 'do apply to the manifestations of the ineffable transcendent reality to humanity, to the personal deities and non-personal 'absolutes' which are the definable objects of religious worship, meditation and much religious experience' (p. 169). These are the products of the Transcendent beyond us and in the depths of our being, using human images and concepts we have created; 'the worshipped deities do not exist apart from the community that worships them' (ibid).

For Pailin, however, to say that verbs which appear to describe divine actions simply 'reify and personify what are really impersonal forces in the ultimate structure of reality is not to clarify their meaning but to hold that the religious faith expressed by them is basically wrong and must be replaced by a fundamentally different kind of understanding' (p. 145). Trigg argues that it is 'not possible to undermine the basis of religion and simultaneously to retain its characteristic ethical claims about humanity' (p. 212). For Trigg, God must make a difference; otherwise we will not be aware of his existence. If he is the creator, he sustains and holds in being what he has created. But if he is merely the ultimate ground of everything, it is hard to see what more is claimed than 'mere acknowledgement of and wonder at the existence of everything' (p. 213).

\section{The metaphor of divine personhood}

We have seen that, if God is a person, he is a person in an analogical sense. If he is personal, only some attributes of persons apply to him. Chief amongst these is the attribute of agency, the interpretation of which is, to say the least, problematic. Some scholars have therefore 
suggested that divine personhood must be understood as a symbol for important spiritual values, as a manifestation of a transcendent reality. But Sallie McFague has suggested that divine personhood is, in fact, a metaphor. Unlike symbols, metaphors 'always contain the whisper, 'it is and it is not" ('Towards a Metaphorical Theology', in John Hick (ed.) Classical and Contemporary Readings in the Philosophy of Religion (Englewood Cliffs, New Jersey: Prentice Hall, 1990), p. 446). There are always some respects in which metaphors differ from the truth they convey; they are often unconventional and surprising.

McFague notes that the central religious language of both the Old Testament and the New Testament is relational; in the Old Testament the focus is on the covenant between God and Israel, and in the New Testament the focus is on persons and 'their way of being in the world in community' (p. 454). Jesus is understood as a parable of God, and personal, relational language is therefore the most appropriate way in which to talk about God (ibid). Jesus was a person relating to other persons 'in loving service and transforming power' ( $p$. 455), and we should aim to do the same. Thus, for McFague, we can say both that we were made in the image of God (Genesis: 3:27), and that we can imagine God in our image. The metaphor of divine personhood must, however, be balanced by the various impersonal images of God which we find in Scripture and tradition - e.g. 'God as rock, fortress, running stream, power, sun, thunder, First Cause, and so on' (p. 455).

\section{Metaphor and divine agency}

But is this, following Pailin and Trigg, merely to personalise an impersonal force, or to construct a God who makes no difference to the world and its creatures? It is not immediately obvious that the objections of Pailin and Trigg are applicable to a view like that of McFague, 
however. On any interpretation of the divine, there are clearly many respects in which God is not like a human person, and, where there do appear to be similarities, the resemblance is always heavily qualified. Thus, it seems not far from saying 'God is a person/personal in an analogical sense' to 'God is a person/personal in a symbolic/ metaphorical sense', from 'not every 'personal' characteristic of God is a literal description of God' to 'perhaps none of the 'personal' characteristics of God must be understood as literal descriptions of God.' If God does not literally walk in the garden of Eden, and if Allah does not literally possess two hands, ${ }^{1}$ then why must we say that God possesses any of the other 'personal' attributes in a literal sense?

But this is not to say that the metaphor of divine personhood is simply a way of talking about impersonal forces which make no difference to human life. On this view, 'God' is the name for whatever it was which brought the universe into existence. It ${ }^{2}$ requires a certain form of life, and provides a standard against which we measure our behaviour. Stories about God, his actions, and what he requires of human beings are stories about the nature of that moral standard and the way in which it requires us, as persons, to behave towards other human persons. There is, therefore, a kind of divine agency; the divine does make a difference to human beings because goodness makes a difference to human beings, both in the way it affects our lives and in the conduct it requires of us.

There is also a relationship between the divine and human beings. If 'relationship' is taken to refer to the way in which things may be connected to each other (See 'Relationship': http://dictionary.reference.com/browse/ relationship), there is relationship in a literal sense. If 'relationship' is understood as 'a connection between persons', the relationship must be understood in either an analogical or a metaphorical sense, however, since there are clearly some respects in which the divine person is not like human persons. Consequently, the nature of the relationship between the divine and human beings is 
unclear and we are obliged to work this out. God is the blueprint for human life, and trying to understand the nature of this blueprint is the task of human life, because it is this which enables us to 'have life, and have it abundantly' (John 10:10). Regrettably, human beings misunderstand the blueprint from time to time, some continually and disastrously so, and this is why dreadful things are sometimes done in the name of religion.

Thus, on many interpretations of theism, from the most conservative to the most liberal, God may and perhaps must be understood as, at least, 'personal'. This is not, however, to be understood in a literal sense; it is a metaphor which conveys, sometimes in perhaps a rather clumsy way, truths which are of great importance for human beings. If understood in a literal or almost literal sense, the idea of divine personhood can be seen as a stumbling block to religious belief; it can seem to some non-believers (e.g. Richard Dawkins, The God Delusion (London: Bantam Press, 2006), pp. 347-352) as if God is not dissimilar from a child's 'imaginary friend'. But, understood as a metaphor with great potential for developing our understanding of the requirements for human fulfilment, divine personhood is, perhaps, one of the most important of God's attributes.

Elizabeth Burns is Lecturer in Philosophy at Heythrop College, University of London.

\section{Notes}

${ }^{1}$ This was commonly interpreted by Muslim scholars as a symbol for divine power, but Ibn Arabi suggested that it is a symbol for the polarities, the opposites, which exist within human beings. See Michael A. Sells, Mystical Languages of Unsaying (Chicago: University of Chicago Press, 1994), p. 86.

2 Although few would claim that God literally has a gender, in the manner of human persons, the lack of a generallyaccepted gender-neutral pronoun in most languages makes it difficult for us to refer to God as both personal and nongendered. 